\title{
Correction to: Mercury bioaccumulation in freshwater fishes of the Chesapeake Bay watershed
}

\author{
James J. Willacker $\mathbb{D}^{1} \cdot$ Collin A. Eagles-Smith $\mathbb{1}^{1} \cdot \operatorname{Vicki}$ S. Blazer $\mathbb{D}^{2}$
}

Published online: 17 April 2021

(c) Springer Science+Business Media, LLC, part of Springer Nature 2021

Correction to: Ecotoxicology

https://doi.org/10.1007/s10646-020-02193-5

In the original publication of this article, the wrong image was provided for Fig. 7. The correct Fig. 7 is provided here.
No results, conclusions, or discussions in the text were affected by this error.

Publisher's note Springer Nature remains neutral with regard to jurisdictional claims in published maps and institutional affiliations.

The original article can be found online at https://doi.org/10.1007/ s10646-020-02193-5.

Collin A. Eagles-Smith

ceagles-smith@usgs.gov

1 U.S. Geological Survey, Forest and Rangeland Ecosystem Science Center, 3200 SW Jefferson Way, Corvallis, OR 97331, USA

2 U.S. Geological Survey, Leetown Science Center, National Fish Health Research Laboratory, 11649 Leetown Road,

Kearneysville, WV 25430, USA 
Fig. 7 Percentage of individual Bluegill (Lepomis macrochirus), Channel Catfish (Ictalurus punctatus), Largemouth Bass (Micropterus salmoides), and Smallmouth Bass (Micropterus dolomieu) mercury

measurements exceeding a whole-body equivalent of $0.30 \mu \mathrm{g} / \mathrm{g}$ wet weight, a level associated with possible reproductive impairment in fishes, within each hydrologic unit (8-digit HUC). Fill patterns indicate whether HUCs had a significantly higher (diagonal bars) or lower (stippling) percentage of fish exceeding the criterion than expected based on each species exceedance across HUCs (chi-squared tests, $\alpha \leq$ 0.05 after adjusting for multiple comparisons). Heavy black lines delineate major sub-watersheds of the Chesapeake Bay Watershed

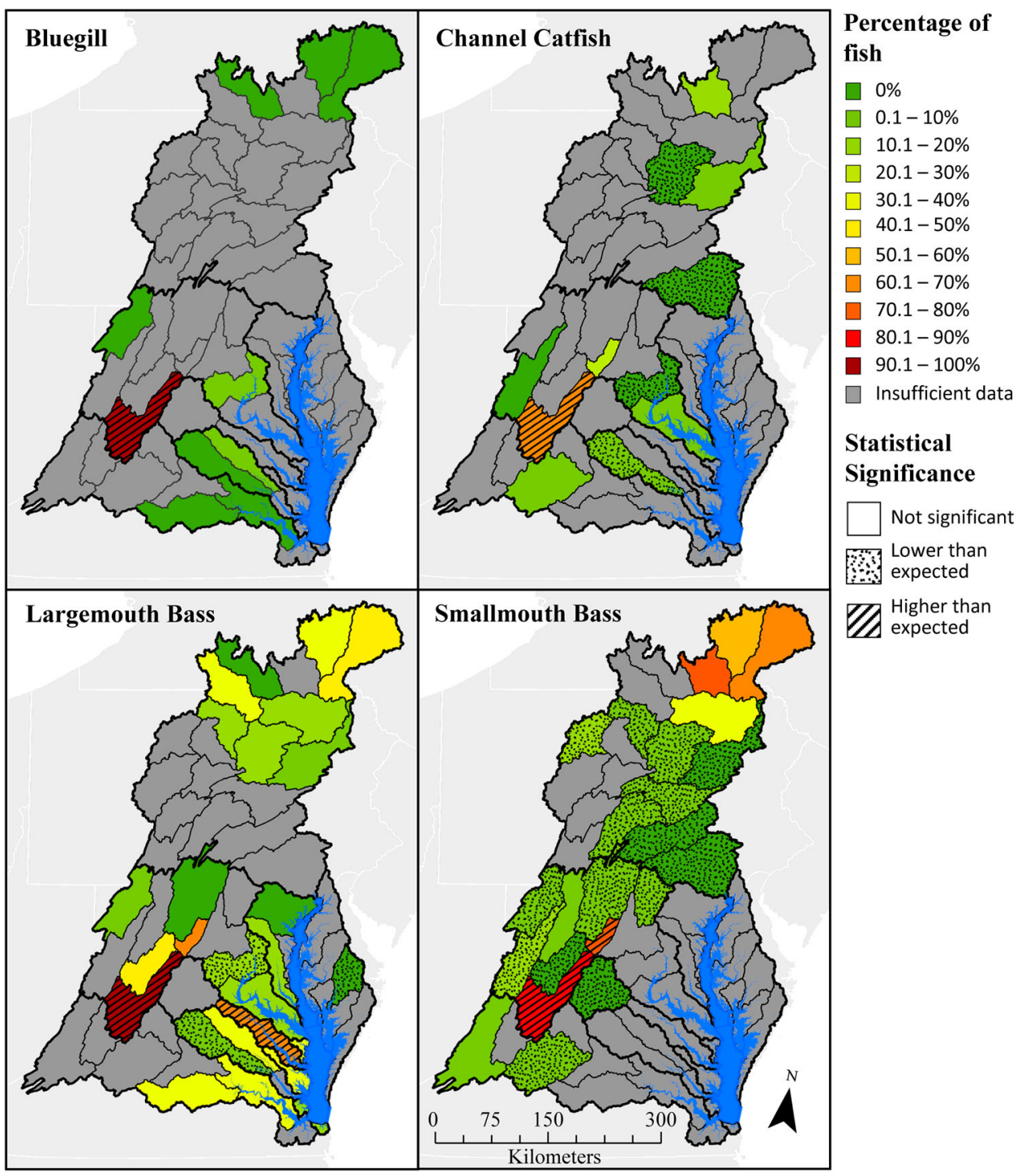

